\title{
sciendo
}

This journal provides immediate open access to its content under the Creative Commons BY 4.0 license. Authors who publish with this journal retain all copyrights and agree to the terms of the above-mentioned CC BY 4.0 license

DOI: 10.2478/seeur-2021-0004

\section{THE CONTROVERSY BETWEEN NIKLAS LUHMANN AND JÜRGEN HABERMAS RELATED TO SOCIOLOGICAL APPROACH TO LAW}

Assoc. Prof. Aleksandar Jovanoski

Law Faculty - Kicevo, str. Rudnicka b.b. Kicevo, University of St. Clement of Ohrid, Bitola, North Macedonia

aleksandar.jovanoski@uklo.edu.mk

Assoc. Prof. Agron Rustemi

Faculty of Contemporary Social Sciences - South Eastern University Tetovo, str. Ilindenska n.335, Tetovo, North Macedonia

a.rustemi@seeu.edu.mk

\begin{abstract}
The aim of the paper is to present a brief insight into the significant works and views of the German sociologists Niklas Luhmann and Jürgen Habermas on the role of law in regulating human relations in society. Educated as a lawyer, Niklas Luhmann in the late academic career was under the influence of the American sociologist Talcott Parsons. Niklas Luhmann later, under the influence of the American sociologist Talcott Parsons, he built a sociological theoretical system called the systems theory. On the other side, Jürgen Habermas was a philosopher and sociologist, highly influenced by the Frankfurt school of sociology. According to Luhmann`s systems theory, the social reality and the separate aspects of the social
\end{abstract}


life are part of a deeper system called society, and in relation to the same they are set as subsystems. Social systems are divided into allopoietic and autopoietic. One of the significant axioms of Luhmann's theory is that the largest number of systems tends to simplify due to the pressure of the environment for greater efficiency. Law in Luhman's systems theory enjoys the status of an autonomous system for regulating society, rather than an instrumental contribution to politics. This brief review exposed a big clash between two influential German thinkers. In this paper we are going to use historical method and analysing of the content of different materials and previous authors that are dealing with the work of Niklas Luhmann and Jürgen Habermas.

Key words: Niklas Luhmann, sociology, law, controversy, systems theory, Jürgen Habermas.

\section{INTRODUCTION}

Niklas Luhmann was born in 1927 in Lineburg, Germany (died 1998) to a family of brewers whose business was pressured by the onslaught of large breweries and liquor stores soon after Niklas was born. In determining the significant socio-historical influences on the character building and education of the young Luhmann, the rise and fall of the Third Reich as well as the Second World War were inevitable. As a 17-year-old mobilized in the air defences of Nazi Germany, Luhmann was also a prisoner of war in the United States at the end of World War II (1945). After the end of World War II, young Luhmann completed his legal studies at the University of Freiburg, and as a law graduate, his first job was as a clerk. A key moment in his university education was his stay in the United States, where he listened to lectures given at the University for a year by the most influential American sociologist, Talcott Parsons. Upon his return from the United States, he began a more serious academic career, first as a collaborator at the research centre of the then-famous Speyer College of Science ${ }^{1}$, the newly opened University of Bielefeld ${ }^{2}$. Jürgen Habermas, was born June 18, 1929, Düsseldorf, Germany. Many sees him as a the most important German philosopher of the second half of

\footnotetext{
1 This was the period when Luhmann published his first book, The Functions and Consequences of Formal Organization (1964).

${ }^{2}$ Significant papers published in this period are: The notion of purpose and systemic rationality (1968); Political Planning (1971); Identity through Procedure (1969) and Legal Sociology (1972) (Source: Vrban, 2006: 159).
} 
the 20th century. A highly influential social and political thinker. Habermas was prominent both outside academic circles for his influential contributions to social criticism and public debate and within them for his voluminous treatises and essays in which he fashioned a comprehensive vision of modern society and the possibility of freedom within it (Matuštík, 2001). Luhmann's more serious breakthrough in academia took place in 1973-74, when a series of controversies began with the already established newest and most trusted representative of the Frankfurt School and the critical sociological thought tradition, Jürgen Habermas. In the period after this well-known polemical debate, Niklas Luhman published six volumes of the work Sociological Enlightenment (Sociologische Aufklärung), the first volume of which was published in 1970 and the last the sixth in 1995.The next phase of Niklas Luhmann's life and academic development marked a rapid breakthrough in his thought and outreach from his Germany, before translating his works into English, but also his stay as a lecturer at universities in the United States, Italy and Brazil.The basic standpoints on Luhmann/Habermas controversy, some authors like Kjaer express in several hypothesis and encounters:

1. The central difference between Habermas' and Luhmann's theoretical positions is reducible to a difference in assessment of the time-consuming character of social operations.

2. Habermas' position is based on the concept of lifeworld; but this concept lacks logical coherence.

3. The concept of reiteration, presented by Luhmann as an alternative to the concept of lifeworld, is logically more stringent.

4. Luhmann's theoretical elaboration nonetheless failed to grasp the importance of context for the constitution of social phenomena, sharply reducing its strength.

5. This shortcoming can be traced to Luhmann's attempt to de-couple systems theory from the German idealist tradition - which he executed via a sophisticated self-mystification strategy, which sought to present systems theory as a new theory, lacking connection to any existing tradition of social thought (Kjaer, 2006:67).

The initial moment of starting Luhmann/Habermas controversy was whether the idea of emancipation through rational political steering - the core element in Enlightenment thinking, as well as in German idealism - could still be considered as meaningful. Luhmann argued that it could not. Habermas conversely advocated for a revitalization of Enlightenment ideals and 
German idealism, to be achieved by the development of an 'updated' theory of emancipation (Kjaer, 2006:66).

\section{EPISTEMOLOGICAL VIEWS}

The aforementioned controversy with Jurgen Habermas, gave Luhmann flight and wind in the back of the young and then unproven lineburg, to be noticed in one of the strongest (if not the strongest) academic scenes in continental Europe, when it came to theoretical discussions on social problems and the role of law. In this respect, it is difficult to bypass the conservative views of Luhmann on the defence of the status quo of the then German society and the philosophy of technocracy (Vrban, 2006: 159). Unlike the critical theorists of the Frankfurt School, who witnessed the devastation of the Nazi way of governing, in every aspect of social life they sought and advocated the emancipation of the unit and the class from the domination of power and technocracy. Luhmann constructs a rather simplified perception of the world, through which his privilege of the existing order is manifested, as well as the neglect of the role of language and the peculiarities of the social systems which in individual views Luhmann equated with those of biological organisms (see Habermas and Luhmann 1974). The peculiar organicism, together with the legacy of Parsons' influence (most evident in the doctrine of the system and the functions of the subsystems), constitute the thread of the theoretical nucleus, which in the decades to come will often categorize Luhmann as a social conservative. One should not omit here the extremely firm, concise and abstract style of writing, which Luhmann made unpopular in the anti-metaphysical academic circles, as is the case with the bent American thought.

Certain authors consider that Luhmann's theory of society as a system is an attempt to break with the so-called Old European thinking, so his theory is to some extent difficult to epistemologically define. Such an assessment is shared, among others, by Dushko Vrban - a Croatian sociologist - who tries to summarize Luhmann's theoretical points of view in three assumptions: first, the systemic approach as the basis of his paradigm, second, a certain constructivism, and third as a kind of postmodern theory (Vrban, 2006: 160). Other authorsconnoisseurs of Luhmann's opus, such as Lidija Topic, consider that the basis of the sociological theory of Niklas Luhmann, called the system theory, is an insult through the concept of system to achieve integration of (knowledge) of different scientific disciplines. It is 
understood, hence the interest and re-actualization of Luhmann's theory, comes as a result of the loss of the position of the dominant theory of Marxism (Topic, 2001: 6-7).

In view of the insight into the state of sociological theories and paradigms, Luhmann is one of the few sociologists who perceive theories through the perspective of the broader "families of theoretical orientations" called paradigms. Considering that in the theories of the system the moment has come for a "paradigm shift", Luhmann appreciates that this change in relation to the general theory of social systems can be shown through three levels of analysis.

According to Luhmann's views, there are ten starting points for systems, according to which the connection of matter can begin - which, according to the empirical knowledge, will be able to embody a set of knowledge and conclusions for the entire theory of systems.

1. There is a consensus today in the profession that the separation of the system and the environment should serve as a starting point for any system analysis.

2. The separation of the system from the environment as a paradigm of the system theory forces the division of the whole and the part to be replaced by a theory for differentiation of systems.

3. Transfiguration of the differentiation between the system and the environment has profound consequences for the understanding of the consequence.

4. The system / environment differentiation must be distinguished from the other equally constitutive differentiations: from the distinction between elements and relations.

5. The central problem of systems theory - regulation refers to the relationship between the elements.

6. The next step introduces the problem of complexity and thus repeats the analysis of the system / environment with the reasons that take it into account the complexity.

7. This connection of the problem of complexity with the analysis of the system is confirmed in a more precise interpretation of the functions of the system boundaries.

8. The conceptual distinction between (concept) system and (concept) complexity has a central position in the following analysis - precisely because complex systems are analyzed.

9. The next central theme is called self-referentiality. In the latest research on the system, self-reference attracts attention, which is rapidly increasing under the headings of selforganization or autopoiesis.

10. Self-referentiality presupposes a principle that could be called a multiple constitution (Luhmann, 2001: 54-86).

Although in sociological theories and theoretical orientations within significant paradigms, one can identify systemic approaches in the study of society or individual social subsystems (such as the organic theories of the origin of society or the teaching of evolutionism by Herbert Spencer's inspiring system), which can be located in the philosophy of Alfred North Whitehead 
and the interdisciplinary approach that enjoyed exceptional popularity in the United States in the 1940s - today known as cybernetics.

In the so-called second phase of the development of cybernetics (the "60s of the last century) is the term general theory of the system, within which the ideas of self-stimulation and selfpreservation of the system begin. In addition, the assumptions that the system itself has the ability to self-monitor (introspection) are accepted. These hypotheses lie in the aforementioned second (mature) phase of systems theory in Luhmann.

Basically, the epistemological foundations of the theoretical views of Niklas Luhmann are diametrically opposed to the classical substantial ontology that begins with Plato and which locates the focus of human consciousness in the search for eternal things (essentialism). In contrast to this current, Luhmann takes a position that many consider postmodern, due to the rejection of the term "subject".

In contrast to Luhmann's emphasis on structural simultaneousness and operative nonsimultaneousness of social operations, Habermas argues that social operations are characteris ed by structural and operative simultaneousness. Habermas' approach derives from the notion of inter-subjectivity, which claims „sprach- und handlungsfähigen Subjekten“ are constituted through their relations to other subjects. Consequently, the existence of a plur ality of subjects must be regarded as a structural condition. This point of departure Habermas combines with the possibility of an operationally-established concordance between two or more subjects' view on the world (Habermas, 1981).

\section{LUHMANN'S THEORY OF LAW}

Luhmann's approach to the study of the entire social reality is often called constructivist. This label only confirms the old epistemological dilemma, present for a long time in sociology (see Robert Merton's reflections on theoretical sociology or Karl Mannheim's "Ideology and Utopia" as an example) as to whether social reality exists as such or it is only a product of the reflections and projections in the minds of sociologists. Going almost in the same direction with the nominalist current in sociological theory, Luhmann argues that there is no reality as an independent entity - subject to examination, and what is called real or reality 
in society is the result of distinctions made by the researcher (sociologist). Hence, science is not discovery, but construction (Luhmann, 2001a: 400, 404).

In his theoretical views, Luhmann always starts from the differentiation of things (things - res) from their description. These and some other reflections of Luhmann's lead some critics to consider him part of the postmodern, while others in his work consider him a skillfully concealed ontology close to classical German idealism (see Miladinov, 2001a: 417-422). In a long series of constructions of system theory, Luhmann uses a series of terms to explain his views. Some of them are borrowed from classical sociologists, but there are also some concepts that Luhmann himself has defined - in order to serve as guidelines with an explanatory function in his theoretical system. As such, the definitions of the terms: system, environment, differentiation, meaning of communication, operation, self-reference, contingency, etc. are considered.

The term system defines it as interconnected elements that can be grouped into smaller units as subsystems. The system is not a static construction and, among other determinants, is the ability for internal selection. Luhmann`s systems can be allopoetic - referring to two subtypes of living systems and systems that create information and meaning; and autopoietic which can be mental and social systems.

Self-referentiality is the observation or ability to observe the basic processes and changes within a system. A system capable of self-referentiality can use the information from the environment for its own benefit, as well as to establish, change and maintain an identity necessary for the survival of the whole system. These systems tend to reduce the complexity that is the result of environmental pressure, and this simplification is most often performed by introducing new differentiations (Vrban, 2006: 165).

Like a good number of prominent sociologists and social thinkers (Max Weber, Karl Marx), Luhmann's legal education served to identify the problems associated with organization, decision-making, and management. This advantage came to the fore especially in view of the German legal tradition in which a sharp distinction is made between legal dogmatics (by the way, in the German language the legal science itself is called Rechtsdogmatik) and other social sciences which in one way or another have a right to touch. In this line of argumentation, Luhmann's first indulgence in his works in the field of sociology of law is the distinction 
between this scientific (sub)discipline and the classical legal disciplines (such as the philosophy of law and the theory of law), while the other tends to conceptualize a framework through which law will be explored in modern society, especially the influence that law has on other social subsystems such as politics and economics.

According to Husserl, Habermas as well as Luhmann himself the function of the concept of lifeworld is to evade the kind of paradoxes on which the late Luhmann focused (Kjaer, 2006: 73). As Kjaer puts:

...the distinction between world and meaning does not seem particularly salient, when it is seen in relationship to the concepts of lifeworld developed by Husserl, Habermas and Luhmann himself, since they all understand the lifeworld as a product of continued social operations, and not as the result of an act of initiation. Consequently, it is difficult to identify the real difference between, on one hand, the intended function of Luhmann's concept of meaning and, on the other, the notion of lifeworld, as it occurs in the works of Husserl and Habermas: both concepts aim at the observation of „frames“ - in other words, contexts - which can be defined as operationally constituted unities, comprising a distinction and both of its sides (Kjaer, 2006: 73).

In general, Luhmann and Habermas agree and advocate the idea that law is an autonomous system for regulating social relations, as opposed to strong insults to the right to be reduced to its instrumental function as a part or aid to other systems.

Given the conceptual register of Luhmann's theory of systems, where law is defined as one of the social subsystems, the definition of the legal system in Luhmann can be followed by three significant diopters:

1. Considering that the legal system is a system of communication, it is an autopoetic system. As such, the legal system is closed to the environment. The two main differences in the legal system are the expectations and the specific binary code.

2. The law is a system that may or may not appear - and it is the mark, which gives the law the property of contingency. Contingency creates the unpredictability and variability that create the environment of the legal system.

3. The key function of the legal system is to stabilize normative expectations. In fact, law successfully amortizes the conflict between the various interests that exist in society. The legal system has the ability to select the expectations that have legal significance 
(as opposed to social or conformist assumptions such as morality, etiquette, decency, etc.)

Another special area of Luhmann's scientific interest is legislation and the judiciary. The special position that the legislation has in the society derives from the goals it sets for the public order and because of the decisions it carries; in other words, it is not customary to follow them later when they produce consequences, nor to redirect those consequences.

Given that society is becoming more complicated, it gives Luhmann a signal to set up the theorem that for the legal system to respond to the needs and challenges of social complexity, it must also differentiate itself internally. The negative course of this whole process is the need for stronger administration, especially in the judiciary, which can seriously undermine the position of the legislature (Vrban, 2006: 168).

\section{CONCLUSION}

Among the most influential names in modern sociology were Niklas Luhmann and Jürgen Habermas. During the '70s, '80s and half of '90s of the twentieth century, these two thinkers developed a debate over the idea of emancipation through rational political steering. Luhmann argued that this is impossible and Habermas on the other hand stands for a revitalization of Enlightenment ideals and German idealism,

Luhmann`s theory of systems, emerged and developed in the last three decades of past century, expressed a sociological theory of law, in which sociological interest emerged at the surface. Sociology of law in the theoretical system of Luhmann once again confirms the previously established theorem that the meaning of the right as an instrument that previously served for social control, must reinvent and maintain its uniqueness as a system. Maintaining this authenticity, the right must acquire its position despite assimilating influences of society.

To sum up, one outcome of the Habermas/Luhmann controversy showed that there are differences in the epistemological standpoints of Habermas' discourse theory as a normative superstructure as opposed to Luhmann's descriptive theory of society. Furthermore, epistemological foundations of the theoretical views of Niklas Luhmann (on law especially) contain a diametrically opposed axioms to the classical substantial ontology. His ontological standpoints diverge from the one that locates the focus of human consciousness in the search 
for eternal things (essentialism). In contrast to this current, Luhmann takes a position that many consider to be postmodern, due to the rejection of the term "subject".

Another outcome is that, beyond the tendency to the two theoretical complexes' convergence, a complete fusion, through the development of a fully-fledged „intersystemic“ and „critical“ systems theory, could provide a viable basis for further theoretical development. Such a theory might provide an optimal frame for the continuing reformulation of legal theory.

One of the realms of theoretical interdependence and consent of ongoing Luhmann/Habermas controversy was that both agree and advocate the idea that law is an autonomous system for regulating social relations, as opposed to strong insults to the right to be reduced to its instrumental function as a part or aid to other systems

This controversy gives a great impetus for further reformulation of new sociological theories of law and basic principles of modern sociology of law. 


\section{REFERENCES}

1. Habermas, J. und Luhman, N. (1974). Theorie der Gesellshaft oder Sozialtechnologie - Was leistet die Systemforschung, Frankfut: Suhrkamp.

2. Habermas, J. (1981). Theorie des kommunikativen Handelns, Band 1. Handlungsrationalität und gesellschaftliche Rationalisierung, Frankfurt am Main: Suhrkamp Verlag.

3. Kjaer. P. F. (2006). "Systems in Context: On the Outcome of the Habermas/LuhmannDebate", Ancilla Iuris, 66-77

4. Luhmann, N. (1999/1981). Ausdifferenzierung des Rechts, Frankfurt: Suhrkamp cited in Vrban, D,2006.

5. Luman, N. (2001). Društveni sistemi: Osnovi opšte teorije, Sremski Karlovci i Novi Sad: Izdavačka knjižarnica Zorana Stojanovića,

6. Luhman, N. (2001a). Znanost društva, Zagreb: KRUG KNJIGA, Politička kultura.

7. Matuštík, M. B. (2001). Jürgen Habermas: A Philosophical-Political Profile. Lanham, MD: Rowman \& Littlefield .

8. Miladinov, K. (2001a) "Pogovor" on book Luhman, N. Znanost društva, Zagreb: KRUG KNJIGA, Politička kultura.

9. Nagl-Docekal, H. and Vetter, H. (1987). Tos des Subjekts? München: cited in Vrban, D. 2006.

10. Topić, L. (2001). 'Teorija sistema kao okvir istraživanja visoko složenih savremenih društava" str. 5-23 во Luman, N. Društveni sistemi: Osnovi opšte teorije, Izdavačka knjizarnica Zorana Stojanovića, Sremski Karlovci i Novi Sad:

11. Vrban, D. (2006). Sociologija prava: Uvod i izvorišne osnove, Zagreb: Golden MarketingTehnička knjiga, 